\title{
HUBUNGAN ANTARA DUKUNGAN TEMAN SEBAYA DENGAN KEPERCAYAAN DIRI BERBICARA DI DEPAN UMUM PADA MAHASISWA
}

\author{
Citra Wahyuni', Emiel Yusuf Costadinov²
}

1,2Program Studi Psikologi Islam, Fakultas Ushuluddin dan Studi Agama, Universitas Islam Negeri Raden Intan Lampung, e-mail: citrawahyuni16@gmail.com

\section{ABSTRACT: THE RELATIONSHIP BETWEEN PEER SUPPORT AND PUBLIC SPEAKING CONFIDENCE AMONG COLLEGE STUDENTS}

Public speaking confidence is influenced by several factors, one of them is peer support. This study aims to determine the relationship between peer support and public speaking confidence in college students. The sample in this study was 70 students of the 2017 Islamic Broadcast Communication Studies Program at the Da'wah and Communication Science Faculty of UIN Raden Intan Lampung. Data collection methods used in this study was self confidence scale and peer support scale. The data that has been collected is then analyzed using Pearson product moment correlation analysis techniques. The results showed the correlation $r x-y=0.817$ and the coefficient of determination $R^{2}=0.667$ with $p=0.000(p>0.05)$. This shows that there is a positive and significant relationship between peer support and confidence in public speaking. This study revealed that the peer support made an effective contribution of $66.7 \%$ on the confidence in public speaking.

\section{Keywords: Peer Support, Self Confidence, Public Speaking, Collede Students}

Kepercayaan diri berbicara di depan umum dipengaruhi oleh beberapa faktor, salah satunya dukungan teman sebaya. Penelitian ini bertujuan untuk mengetahui hubungan antara dukungan teman sebaya dengan kepercayaan diri berbicara di depan umum pada mahasiswa. Sampel pada penelitian ini adalah 70 mahasiswa Program Studi Komunikasi Penyiaran Islam angkatan 2017 pada Fakultas Dakwah dan IImu Komunikasi UIN Raden Intan Lampung. Metode pengumpulan data pada penelitian ini menggunakan skala kepercayaan diri dan skala dukungan teman sebaya. Data yang telah terkumpul kemudian dianalisis dengan menggunakan teknik analisis korelasi pearson product moment. Hasil penelitian menunjukkan korelasi $r x-y=0,817$ dan koefisien determinasi $R^{2}=0,667$ dengan $p=0,000(p>0,05)$. Hal tersebut menunjukan bahwa adanya hubungan yang positif dan signifikan antara dukungan teman sebaya dengan kepercayaan diri berbicara di depan umum. Penelitian ini mengungkapkan bahwa variabel dukungan teman sebaya memberikan sumbangan efektif sebesar $66,7 \%$ pada variabel kepercayaan diri berbicara di depan umum.

\section{Kata kunci: Dukungan Teman Sebaya, Kepercayaan Diri, Berbicara di Depan Umum, Mahasiswa}

\section{PENDAHULUAN}

Komunikasi merupakan suatu hal yang sangat penting. Banyak tokoh besar di dunia mampu mempengaruhi beribu-ribu, bahkan berjuta-juta orang dengan kemampuan berbicara atau berkomunikasi (Yusuf, 2006). Walaupun begitu, didalam kehidupan sehari-hari tidak banyak orang yang percaya diri saat berbicara dengan orang lain meskipun hanya sekedar membahas permasalahan kehidupan pribadi ataupun hanya berpendapat dengan alasan takut, dan sebagainya.

Tuntutan keterampilan komunikasi

pada mahasiswa menurut Undang-Undang Republik Indonesia nomor 20 Tahun 2003 di implementasikan pada proses pembelajaran yang berpusat pada siswa atau disebut dengan 


\section{HUBUNGAN ANTARA DUKUNGAN TEMAN SEBAYA DENGAN KEPERCAYAAN DIRI BERBICARA DI DEPAN UMUM PADA MAHASISWA}

Student Centered Learning (SCL) pada metode tersebut, mashasiswa berperan sebagai subjek yang aktif dan mandiri serta bertanggung jawab sepenuhnya atas pembelajarannya. Salah satu kegiatan yang dapat dilakukan yakni diskusi, memberikan kesempatan pada mahasiswa untuk berlatih keterampilan mengkritisi dan komunikasi. Pada Perguruan Tinggi Keagamaan Islam (PTKI), salah satu implementasi kemampuan komunikasi mahasiswa adalah dengan kegiatan berdakwah.

Fakultas pada (PTKI) yang memiliki tujuan untuk menghasilkan lulusan yang mampu berdakwah adalah Fakultas Dakwah dan IImu Komunikasi, secara khusus, program studi yang dimaksud adalah program studi Komunikasi Penyiaran Islam (KPI). Pada program studi KPI mahasiswa dibekali ilmu dan keterampilan berkomunikasi untuk kepentingan syi'ar Islam (dakwah). Berdasarkan kurikulum di program studi KPI, mahasiswa belajar atau mendalami dua hal yaitu Islam dan Komunikasi, yakni mahasiswa dituntut untuk dapat mendalami ilmu Agama Islam dan keterampilan menyebarkannya melalui media.

Menurut penelitian Alfandi (2005) menerangkan bahwa mahasiswa program studi KPI diharapkan memiliki keterampilan dalam mensyiarkan ajaran Islam dengan sarana tradisional (mimbar) maupun dengan media modern (cetak dan elektronik seperti televisi dan radio. Berdasarkan harapan tersebut mahasiswa perlu melakukan beberapa tugas yang menunjang terbentuknya keterampilan komunikasi salah satunya adalah ceramah. Tetapi tidak sedikit para mahasiswa yangkurang percaya diri ketika harus menjadi pembicaradidepan umum untukmenyampaikan materi dakwah atau hanyasekedar peresentasi/diskusi makalah didepan kelas. Fenomenayang terjadi di kalangan mahasiswa saat ini mereka lebih senang menjadi pendengardari pada harus berdiri di depan menjadi pembicara.

Salah satu mata kuliah pada prodi KPI yang berkaitan dengan kemampuan berdakwah adalah praktikum dakwah. Mahasiswa dan mahasiswi diwajibkan untuk melaksanakan dakwah, yakni berceramah di masjid-masjid di wilayah Bandar Lampung. Berdasarkan wawancara peneliti pada bulan maret tahun 2019 dari 100 mahasiswa yang berasal dari angkatan tahun 2013, 2014 dan 2015 hanya35 mahasiswa yang benar-benar menyampaikan ceramahnya di masjid. Fenomena tersebut tidak hanya terjadi pada pelaksanaan praktikum dakwahtahun akademik 2013, 2014 dan 2015 akan tetapi selalu terjadi pada praktikum dakwah sebelumnya. Berdasarkan penjelasan di atas, dapat disimpulkan bahwa terdapat banyak mahasiswa yang tidak percaya diri berbicara di depan umum dan ada sebagian kecil yang mengaku percaya diri ketika berbicara di depan umum.

Citra Wahyuni, Program Studi Psikologi Islam, Fakultas Ushuluddin dan Studi Agama, Universitas Islam Negeri Raden Intan Lampung, e-mail: citrawahyuni16@gmail.com

Emiel Yusuf Costadinov, Program Studi Psikologi Islam, Fakultas Ushuluddin dan Studi Agama, Universitas Islam Negeri Raden Intan Lampung. 


\section{HUBUNGAN ANTARA DUKUNGAN TEMAN SEBAYA DENGAN KEPERCAYAAN DIRI BERBICARA DI DEPAN UMUM PADA MAHASISWA}

Data tersebut diperkuat dengan dilakukannya observasi pada sesi persentasi, di kelas B mahasiswa jurusan KPI Fakultas Dakwah dan Komunikasi pada angkatan 2017. Observasi tersebut dilakukan pada tanggal 6 September 2019. Terdapat beberapa mahasiswa yang tidak memahami isi dari materi yang disampaikan, kurang jelas saat menyampaikan materi, beberapa mahasiswa juga mentertawakan teman-temannya ketika melakukan kesalahan menjelaskan isi materi didepan dan ada juga mahasiswa yang tidak bisa menjawab pertanyaan yang diajukan saat sesi tanya jawab dan ada yang merasa malu dan canggung saat menyampaikan materi.

Berdasarkan hasil observasi tersebut, peneliti melakukan wawancara terbuka pada tanggal 6 September 2019 dengan lima orang mahasiswa program studi KPI angkatan 2017, terdapattigamahasiswa diantaranya tidak yakin akan kemampuannya dalam menyampaikan materi, merasa takut tidak bisa menyampaikan materi dengan baik dan mereka merasa tidak sepadan atau merasa lebih rendah diri dibanding teman-temannya, merasa kurang dihargai oleh teman-temannya, dan juga takut ditertawakan saat berbicara atau mengemukakan pendapatnya.Dari hal tersebut terungkap bahwa beberapa mahasiswa kurang mendapatkan dukungan teman sebaya. Mahasiswa yang mendapatkan dukungan teman sebayanya yang rendah akan merasa bahwa dirinya terasingkan, kurang mendapatkan perhatian dan kasih sayang dari temansebaya sehingga kurang memiliki kepercayaan diri.

Lebih lanjut untuk memperkuat data, peneliti akhirnya melakukan wawancara dengan sekjur program studi KPI pada tanggal 13 September 2019 di ruang program studi KPI. Beliau mengatakan bahwa memang terdapat beberapa mahasiswa prodi KPI yang tidak percaya diri berbicara di depan umum. Hal tersebut dikarenakan mahasiswa merasa gugup, menjelaskan materi dengan terbata-bata, juga mahasiswa kurang memahami isi materi yang ingin disampaikan, tidak berani dalam mengemukakan pendapatnya, dan beberapa mahasiswa ada yang takut salah dalam menyampaikan materi yang pada akhirnya ditertawakan oleh teman-temannya. Menurut beliau jika tindakan-tindakan tersebut sering di alami mahasiswa, ini akan membuat mahasiswa tidak percaya diri berbicara di depan umum. Beliau juga menerangkan bahwasanya mahasiswa yang tidak percaya diri berbicara di depan umum ini di karenakan kurang nya memahami materi yang disampaikan, serta banyak yang kurang menghargai dengan mentertawakan performa temannya. Beliau menjelaskan bahwa meningkatkan rasa percaya diri pada mahasiswa adalah dengan menghargai apapun yang mereka lakukan selagi itu positif. Maka mahasiswa tersebut akan merasa telah

Citra Wahyuni, Program Studi Psikologi Islam, Fakultas Ushuluddin dan Studi Agama, Universitas Islam Negeri Raden Intan Lampung, e-mail: citrawahyuni16@gmail.com

Emiel Yusuf Costadinov, Program Studi Psikologi Islam, Fakultas Ushuluddin dan Studi Agama, Universitas Islam Negeri Raden Intan Lampung. 


\section{HUBUNGAN ANTARA DUKUNGAN TEMAN SEBAYA DENGAN KEPERCAYAAN DIRI BERBICARA DI DEPAN UMUM PADA MAHASISWA}

melakukan yang terbaik yang bisa mereka lakukan dan tidak takut untuk terus berkembang.

Stankov, Morony dan Ping (2010) mengungkapkan bahwa keperpercayaan diri merupakan modal dasar untuk pengembangan aktualitas diri. Dengan percaya diri orang akan mampu mengenal dan memahami diri sendiri. Sementara itu, kurangnya percaya diri akan menghambat pengembangan potensi diri. Individu yang kurang percaya diri akan menjadi seseorang yang pesimis dalam menghadapi tantangan, takut dan ragu-ragu untuk menyampaikan gagasan, serta bimbang dalam menentukan pilihan dan sering membandingbandingkan dirinya dengan orang lain. Sependapat dengan Ryan dan Deci (2000) yang mengatakan bahwa kepercayaan diri adalah percaya akan kemampuan terbaik diri sendiri yang memadai dan menyadari kemampuan yang dimiliki, dapat memanfaatkannya secara tepat untuk menyelesaikan serta menanggulangi suatu masalah dengan situasi terbaik dan dapat memberikan sesuatu yang menyenangkan bagi orang lain. Rasa percaya diri adalah suatu keyakinan seseorang terhadap segala aspek kelebihan yang dimilikinya dan keyakinan tersebut membuatnya merasa mampu untuk dapat mencapai berbagai tujuan di dalam hidupnya (Hakim, 2002). Kepercayaan diri adalah keyakinan akan kekuatan, keterampilan dan kemampuan untuk menghasilkan sesuatu.
Menurut Lauster (2003) kepercayaan diri merupakan suatu sikap atau keyakinan atas kemampuan diri sendiri, sehingga dalam tindakan-tindakannya tidak terlalu cemas, merasa bebas untuk melakukan hal-hal yang sesuai dengan keinginan dan tanggung jawab atas perbuatannya, sopan dalam berinteraksi dengan orang lain, memiliki dorongan prestasi serta dapat mengenal kelebihan dan kekurangan diri sendiri. Santrock (2003) mengatakan bahwa salah satu faktor yang mempengaruhi kepercayaan diri remaja yaitu dukungan sosial teman sebaya.

Rook (dalam Hunt, Paul, dan Chester, 2011) mengatakan bahwa dukungan teman sebaya merupakan salah satu fungsi dari ikatan sosial, dan ikatan-ikatan sosial tersebut menggambarkan tingkat kualitas umum dari hubungan interpersonal. Ikatan dan persahabatan dengan orang lain dianggap sebagai aspek yang memberikan kepuasan secara emosional dalam kehidupan individu. Saat seseorang didukung oleh lingkungan maka segalanya akan terasa lebih mudah. Dukungan teman sebaya menunjukkan pada hubungan interpersonal yang melindungi individu terhadap konsekuensi negatif dari stres. Dukungan teman sebaya yang diterima dapat membuat individu merasa tenang, diperhatikan, dicintai, timbul rasa percaya diri dan kompeten.

Sesuai dengan hal tersebut menurut Saronson (dalam Rahmadita, 2013)

Citra Wahyuni, Program Studi Psikologi Islam, Fakultas Ushuluddin dan Studi Agama, Universitas Islam Negeri Raden Intan Lampung, e-mail: citrawahyuni16@gmail.com

Emiel Yusuf Costadinov, Program Studi Psikologi Islam, Fakultas Ushuluddin dan Studi Agama, Universitas Islam Negeri Raden Intan Lampung. 


\section{HUBUNGAN ANTARA DUKUNGAN TEMAN SEBAYA DENGAN KEPERCAYAAN DIRI BERBICARA DI DEPAN UMUM PADA MAHASISWA}

menerangkan bahwa dukungan teman sebaya dapat dianggap sebagai sesuatu keadaan yang bermanfaat bagi individu yang diperoleh dari orang-orang yang dapat dipercaya.Dari keadaan tersebut individu akan mengetahui bahwa orang lain memperhatikan, menghargai, dan mencintainya.Keberadaan teman sebaya dalam kehidupan remaja merupakan keharusan. Dukungan perhatian, kasih sayang, nasehat dan keperdulian dari teman sebaya membuat remaja merasa diterima oleh lingkungan sosialnya (Santrock, 2003). Hal ini akan menumbuhkan perasaan berharga pada diri remaja sehingga akan muncul sikap percaya diri yang dicerminkan sikap tidak mudah menyerah, bertanggung jawab, berani menjadi diri sendiri dan mempunyai cara pandang yang positif terhadap diri sendiri.

Dari data lapangan yang sudah ditemukan dan dikaitkan dengan teori yang ada dapat disimpulan bahwa terjadinya penurunan jumlah mahasiswa yang benar-benar menyampaikan ceramah dari tahun ke tahun karena faktor ketidak percayaan diri, malu dan gugup jika berdiri di depan banyak orang untuk menjadi pembicara sehingga perlunya faktor pendukung untuk meningkatkan kepercayaan diri pada mahasiswa tersebut.Sesuai dengan penelitian yang telah dilakukan oleh Evitasari, Lestari, dan Lestari (2005) dalam penelitiannya yang berjudul Hubungan Antara Dukungan Sosial Dengan Kepercayaan Diri Pada Siswa
SMA Inklusi. Hasil penelitian menunjukkan bahwa ada hubungan positif yang sangat signifikan antara dukungan sosial dengan kepercayaan diri. Artinya semakin tinggi dukungan sosial individu maka semakin tinggi kepercayaan diri, dan sebaliknya semakin rendah dukungan sosial individu maka semakin rendah pula kepercayaan diri pada siswa SMA Muhammadiyah 6 Surakarta, berdasarkan hasil penelitian diketahui dukungan sosial dan kepercayaan diri pada subyek penelitian tergolong tinggi.

Berdasarkan latar belakang masalah yang telah di uraikan, maka rumusan masalah dalam penelitian ini apakah ada hubungan antara dukungan teman sebaya dengan kepercayaan diri berbicara di depan umum pada mahasiswa di Fakultas Dakwah dan Komunikasi UIN Raden Intan Lampung?

\section{METODE}

Sampel pada penelitian ini adalah 70 mahasiswa prodi KPI angkatan 2017 yang diperoleh dengan teknik proportionate random sampling. Pengambilan sampel menggunakan $25 \%$ dari jumlah mahasiswa setiap kelas angkatan 2017.

Penelitian ini menggunakan dua skala, yakni skala kepercayan diri dan skala dukungan teman sebaya. Skala kepercayaan diri disusun oleh peneliti dengan mengacu pada lima aspekyang dikemukakan oleh Lauster (2003)

Citra Wahyuni, Program Studi Psikologi Islam, Fakultas Ushuluddin dan Studi Agama, Universitas Islam Negeri Raden Intan Lampung, e-mail: citrawahyuni16@gmail.com

Emiel Yusuf Costadinov, Program Studi Psikologi Islam, Fakultas Ushuluddin dan Studi Agama, Universitas Islam Negeri Raden Intan Lampung. 


\section{HUBUNGAN ANTARA DUKUNGAN TEMAN SEBAYA DENGAN KEPERCAYAAN DIRI BERBICARA DI DEPAN UMUM PADA MAHASISWA}

yaitu keyakinan akan kemampuan diri, optimisme, objektif,tanggungjawab, dan rasionalitas dalam menghadapi masalah. Hasil perhitungan validitas skala kepercayaan diridengan37 aitem yang telah diujicobakan terdapat enam aitem yang gugur dan 31 aitem valid. Aitem yang valid tersebut memiliki korelasi aitem total yang berkisar antara 0,250 sampai 0,784 . Koefisien realibiltas alpha (cronbach's alpha) pada skala kepercayaan diri adalaha = 0,930 yang berarti skala tersebut reliabel.

Skala dukungan teman sebaya yang digunakan dalam penelitian ini adalah modifikasi dari skala yang digunakan oleh Wahyudi (2016). Hasil perhitungan validitasskala dukungan teman sebayadengan31 aitem menunjukkan bahwa terdapat 10 aitem yang gugur dan 21 aitem valid, dengan korelasi aitem total berkisar berkisar antara 0,250 sampai 0,659. Koefisien reliabilitas alpha (cronbach's alpha)pada skala dukungan teman sebayaadalah $a=0,894$ yang berarti aitem tersebut reliabel.

Teknik analisis data yang digunakan dalam penelitian ini adalah korelasi product moment Pearson. Peneliti menggunakan teknik analisis data tersebut untuk mengetahui keeratan hubungan dua variabel dan sumbangan efektif variabel bebas (dukungan teman sebaya) terhadap variabel terikat (kepercayaan diri).

\section{HASIL}

Hasil penelitian ini terdiri dari hasil uji statistik deskriptif dan hasil uji korelasi. Uji statistik deskriptif menghasilkan kategorisasi data kepercayaan diri yang dapat dilihat pada Tabel 2 berikut.:

\section{Tabel 1.}

Kategorisasi Data Kepercayaan Diri

\begin{tabular}{cccc}
\hline Kategori & $\begin{array}{c}\text { Rentang } \\
\text { Skor }\end{array}$ & Frekuensi & $\begin{array}{c}\text { Persentase } \\
(\%)\end{array}$ \\
\hline Tinggi & $93 \leq \mathrm{X}$ & 46 & $65.7 \%$ \\
Sedang & $62 \leq \mathrm{X}<93$ & 24 & $34.3 \%$ \\
Rendah & $\mathrm{X}<62$ & 0 & $0 \%$ \\
\hline \multicolumn{2}{c}{ Total } & 70 & $100 \%$ \\
\hline
\end{tabular}

Berdasarkan Tabel 2 diatas dapat diketahui bahwa sebagian besar mahasiswa memiliki skor kepercayaan diri yang tinggi, yaitu sebesar $65.7 \%$ Kategorisasi data dukungan teman sebaya dapat dilihat pada Tabel 3 di bawah ini.

Citra Wahyuni, Program Studi Psikologi Islam, Fakultas Ushuluddin dan Studi Agama, Universitas Islam Negeri Raden Intan Lampung, e-mail: citrawahyuni16@gmail.com

Emiel Yusuf Costadinov, Program Studi Psikologi Islam, Fakultas Ushuluddin dan Studi Agama, Universitas Islam Negeri Raden Intan Lampung. 


\section{HUBUNGAN ANTARA DUKUNGAN TEMAN SEBAYA DENGAN KEPERCAYAAN DIRI BERBICARA DI DEPAN UMUM PADA MAHASISWA}

Tabel 2.

Kategorisasi Data Dukungan Teman Sebaya

\begin{tabular}{cccc}
\hline Kategori & $\begin{array}{c}\text { Rentang } \\
\text { Skor }\end{array}$ & Frekuensi & $\begin{array}{c}\text { Persentase } \\
(\%)\end{array}$ \\
\hline Tinggi & $63 \leq \mathrm{X}$ & 44 & $62,9 \%$ \\
Sedang & $42 \leq \mathrm{X}<63$ & 26 & $37,1 \%$ \\
Rendah & $\mathrm{X}<42$ & 0 & $0 \%$ \\
\hline \multicolumn{2}{c}{ Total } & 70 & $100 \%$ \\
\hline
\end{tabular}

Berdasarkan Tabel 3 diatas, dapat diketahui bahwa sebagian besar mahasiswa memiliki dukungan teman sebaya dalam kategori tinggi, yaitu sebesar $62,9 \%$.

Hasil uji hipotesis menggunakan korelasi product-moment Pearson dapat dilihat dari Tabel 4 dibawah ini:

\section{Tabel 3.}

Hasil Uji Hipotesis

\begin{tabular}{cccc}
\hline Variabel & $R$ & $R^{2}$ & Sig \\
\hline$X^{*} Y$ & 0,817 & 0,667 & 0,000 \\
\hline
\end{tabular}

Berdasarkan Tabel4 diatas, dapat dilihat bahwa hubungan antara variabel bebas yaitu dukungan teman sebaya dengan variabel terikat yaitu kepercayaan diri diperoleh nilai koefisien korelasi $r x-y=0,817$ dan koefisien determinasi $R^{2}=0,667$ dengan $p=0,000(p<0,05)$. Hasil tersebut menunjukan bahwa ada hubungan yang positif dan signifikan antara dukungan teman sebaya dengan kepercayaan diri berbicara di depan umum pada mahasiswa.

Nilai korelasi product moment antara variabel dukungan teman sebaya dengan kepercayaan diri adalah 0,817 lalu dikuadratkan menjadi 0,667 dan dipersen kan menjadi 66,7\%. Hasil perhitungan tersebut menunjukkan bahwa variabel dukungan teman sebaya memberikan sumbangan efektif sebesar $66,7 \%$ pada variabel kepercayaan diri berbicara di depan umum.

\section{DISKUSI}

Berbicara dengan manusia didepan
umum merupakan salah satu keterampilan
dalam menyampaikan informasi yang harus
dimiliki setiap orang. Mahasiswa yang
menyampaikan dakwah bisa menunjukan
ketidakpercayaan diri berbicara di depan umum

yang disebabkan oleh beberapa fakor, yakni ketrampilan komunikasi, faktor individu dan faktor lingkungan. Oleh karena itu mahasiswa yang hendak berbicara didepan umum harus banyak persiapan dan percaya diri.Bagi mahasiswa prodi KPI yang masih belajar berbicara di depan umum berupa

Citra Wahyuni, Program Studi Psikologi Islam, Fakultas Ushuluddin dan Studi Agama, Universitas Islam Negeri Raden Intan Lampung, e-mail: citrawahyuni16@gmail.com

Emiel Yusuf Costadinov, Program Studi Psikologi Islam, Fakultas Ushuluddin dan Studi Agama, Universitas Islam Negeri Raden Intan Lampung. 


\section{HUBUNGAN ANTARA DUKUNGAN TEMAN SEBAYA DENGAN KEPERCAYAAN DIRI BERBICARA DI DEPAN UMUM PADA MAHASISWA}

menyampaikan dakwah merupakan suatu tantangan tersendiri.

Kepercayaan diri merupakan kunci utama dalam berbicara didepan umum. Seperti yang diungkapkan oleh Lauster (2003) kepercayaan diri berbicara di depan umum adalah sebagai suatu sikap atau perasaan yakin akan kemampuan diri sendiri, sehingga seseorang tidak terpengaruh oleh orang lain. Mahasiswa yang percaya diri akan menyampaikan dakwah dengan yakin kepada masyarakat, mahasiswa tersebut akan menyampaikan materi dakwahnya dengan baik.

Begitu pentingnya kepercayaan diri yang tinggi yang harus dimiliki oleh mahasiswa prodi KPI dalam menyampaikan dakwah, sehingga perlu dicari faktor yang dapat mempengaruhi kepercayaan diri pada individu. Menurut Fleming (2004) bahwa salah satu yang mempengaruhi kepercayaan diri adalah dukungan social teman sebaya. Dukungan sosial tersebut termasuk membantu dan menolong pada teman, keluarga, dan memberikan waktu yang dibutuhkan. Menurut Sarafino dan Smith (1994) dukungan sosial mengacu pada kenyamanan, perhatian, penghargaan, atau bantuan yang diberikan teman sebaya baik individu atau kelompok kepada seseorang.

Kepercayaan diri butuh adanya dukungan penghargaan sepertimemberikan ekspresi yang berupa pernyataan setuju dan penilaian positif terhadap ide-ide, saran, perasaan dan performa orang lain. Mahasiswa yang sedang belajar menyampaikan dakwah membutuhkan saran berupa respon positif dan ide kreatif dalam menyampaikan dakwah. Dukungan ini akan membuat mahasiswa menganalisa secara positif permasalahan yang dihadapinya dalam menyampaikan dakwah dan memikirkan solusi untuk menyelesaikan masalah tersebut.

Begitu juga dengan dukungan emosional, mahasiswa yang diberikan rasa empati dan perhatian dari teman sebaya, akan membuatmahasiswa tersebut merasa nyaman, dicintai dan diperhatikan. Dukungan ini meliputi perilaku seperti memberikan perhatian dan afeksi serta bersedia mendengarkan keluh kesah. Hal ini akan membuat sikap positif mahasiswa tentang dirinya bahwa ia mengerti sungguh-sungguh akan apa yang dilakukan untuk menyampaikan dakwah.

$\mathrm{Hal}$ ini sesuai dengan dukungan instrumental, dukungan ini melibatkan bantuan langsung, yang berupa bantuan finansial atau bantuan dalam melaksanakan praktikum dakwah, seperti penyediaan barang dan peralatan pendukung dalam menyampaikan dakwah. Dukungan ini akan membuat kesediaan mahasiswa untuk menanggung segala sesuatu yang telah menjadi konsekuensinya untuk memecahkan suatu masalah dan belajar untuk bertanggung jawab.

Citra Wahyuni, Program Studi Psikologi Islam, Fakultas Ushuluddin dan Studi Agama, Universitas Islam Negeri Raden Intan Lampung, e-mail: citrawahyuni16@gmail.com

Emiel Yusuf Costadinov, Program Studi Psikologi Islam, Fakultas Ushuluddin dan Studi Agama, Universitas Islam Negeri Raden Intan Lampung. 


\section{HUBUNGAN ANTARA DUKUNGAN TEMAN SEBAYA DENGAN KEPERCAYAAN DIRI BERBICARA DI DEPAN UMUM PADA MAHASISWA}

Berdasarkan penjelasan diatas terlihat bahwa dukungan sosial teman sebaya dapat memberikan pengaruh terhadap kepercayaan diri berbicara di depan umum. Teman sebaya bagi mahasiswa memiliki fungsi psikologis yang penting karena selain sebagai tempat berinteraksi juga dapat merupakan sumber dukungan sosial bagi mahasiswa. Keakraban dengan saling berbagi perasaan, memberikan saran serta ide-ide kreatif dan memberikan bantuan dalam melaksanakan praktikum dakwah dapat mempengaruhi kepercayaan diri berbicara di depan umum.

\section{SIMPULAN DAN SARAN}

$$
\begin{aligned}
& \text { Terdapat hubungan positif dan } \\
& \text { signifikan antara dukungan teman sebaya } \\
& \text { dengan kepercayaan diri berbicara di depan } \\
& \text { umum pada mahasiswa prodi KPI Fakultas } \\
& \text { Dakwah dan llmu Komunikasi UIN Raden Intan } \\
& \text { Lampung.Artinya, semakin tinggi dukungan } \\
& \text { teman sebaya mahasiswa maka semakin tinggi } \\
& \text { pula kepercayaan dirinyaberbicara di depan } \\
& \text { umum. Sebaliknya, semakin rendah dukungan } \\
& \text { teman sebaya mahasiwa maka semkain rendah } \\
& \text { keercayaandirinyadalam berbicara di depan } \\
& \text { umum. } \\
& \text { Hasil penelitian ini memberikan } \\
& \text { implikasi bahwa mahasiswa diharapkan memiliki } \\
& \text { pengendalian diri yang baik, dan dapat selalu } \\
& \text { meningkatkan rasa kepercayaan dirinya dengan } \\
& \text { memotivasi diri bahwa mereka bisa apabila mau }
\end{aligned}
$$

berusaha keras. Lanjut lagi agar mahasiswa dapat lebih mempersiapkan diri lagi dalam melaksanakan praktikum dakwah, seperti lebih mendalami isi materi dan membuat suatu kelompok belajar dengan teman sebaya agar bisa saling memberikan ide saran dan kritik dalam penyampaian materi dakwahnya.

\section{DAFTAR PUSTAKA}

Alfandi, M. (2005). Format Dakwah Melalui Media Televisi. Jurnal IImu Dakwah, 25, 43-56.

Evitasari, T. S., Lestari, R., Psi, S., Lestari, R., \& Psi, S. (2017). Hubungan Antara Dukungan Sosial Dengan Kepercayaan Diri Pada Siswa SMA Inklusi (Doctoral dissertation, Universitas Muhammadiyah Surakarta).

Hakim, T. (2002). Mengatasi rasa tidak percaya diri. Jakarta: Puspa Swara.

Hunt, H., Paul, B., \& Chester, L. (2011). Sosiologi: Edisi Keduabelas. Jakarta: Erlangga.

Lauster, P. (2003). Tes Kepercayaan diri. Jakarta. PT. Bumi Aksara.

Rahmadita, I. (2013). Hubungan antara konflik peran ganda dan dukungan sosial pasangan dengan motivasi kerja pada karyawati di Rumah Sakit Abdul RivaiBerau. Jurnal Psikologi, 1(1), 58-68.

Ryan, R. M., \& Deci, E. L. (2000). Intrinsic and extrinsic motivations: Classic definitions and new directions. Contemporary educational psychology, 25(1), 54-67.

Citra Wahyuni, Program Studi Psikologi Islam, Fakultas Ushuluddin dan Studi Agama, Universitas Islam Negeri Raden Intan Lampung, e-mail: citrawahyuni16@gmail.com

Emiel Yusuf Costadinov, Program Studi Psikologi Islam, Fakultas Ushuluddin dan Studi Agama, Universitas Islam Negeri Raden Intan Lampung. 
HUBUNGAN ANTARA DUKUNGAN TEMAN SEBAYA DENGAN KEPERCAYAAN DIRI BERBICARA DI DEPAN UMUM PADA MAHASISWA

Santrock, J. W. (2003). Adolescence perkembangan remaja. Jakarta: Erlangga, 422-4.

Sarafino, E. P., \& Smith, T. W. (2014). Health psychology: Biopsychosocial interactions. John Wiley \& Sons.
Stankov, L., Morony, S. A., \& Ping, L.Y. (2010). Strong links between self-confidence and math performance.Singteac, Research within Reach, 29.

Wahyudi, Q. (2016). Pengaruh dukungan sosial terhadap psychological well-being narapidana usia remaja. (Skripsi Tidak Diterbitkan) Universitas Muhammadiyah Malang,Malang

Yusuf, P. M. (2019). Ilmu informasi, komunikasi dan kepustakaan.

Citra Wahyuni, Program Studi Psikologi Islam, Fakultas Ushuluddin dan Studi Agama, Universitas Islam Negeri Raden Intan Lampung, e-mail: citrawahyuni16@gmail.com

Emiel Yusuf Costadinov, Program Studi Psikologi Islam, Fakultas Ushuluddin dan Studi Agama, Universitas Islam Negeri Raden Intan Lampung. 